\title{
HISTORY OF ELECTROCARDIOLOGY
}

\section{Introductory Note to a Classic Article by Augustus D. Waller}

\author{
Arthur J. Moss, M.D. \\ From the Cardiology Unit, Department of Medicine, University of Rochester School of Medicine and Dentistry, \\ Rochester, New York
}

August D. Waller was graduated from the University of Edinburgh with a medical degree in 1881. Dr. Waller made many contributions to physiology and medicine including the influence of anesthetic gases (ether and chloroform) on the irritability of nerves and muscles. He is best known for his recording and publication of the first human electrocardiogram in Journal of Physiology in 1887 entitled "A Demonstration on Man of Electromotive Changes Accompanying the Heart's Beat" ${ }^{1}$ and reprinted in this history of cardiology section of Annals of Noninvasive Electrocardiology (ANE). The recording was made without opening the chest.

The "electromotive changes" were recorded with a capillary electrometer built by Thomas Goswell, a technician in his laboratory. The capillary electrometer was invented by the French physicist, Gabriel Lippmann, in 1872. It is a thin glass tube with a column of mercury beneath sulphuric acid (Fig. 1). The mercury meniscus moves with varying electrical potential and is observed through a microscope and photographed. Because of the inertia of mercury, the movements of the mercury meniscus were severely damped, and this is evident in the figures in the accompanying article by Waller. A few years later, Dr. G. J. Burch of Oxford devised an arithmetical correction for the observed damped fluctuations of the mercury meniscus.

The initial deflections prior to the correction formula were labeled A, B, C, and D. Einthoven used the term "electrocardiogram" at a meeting of the Dutch Medical Association in 1893 (later he claimed that Waller was the first to use the term; Lancet 1912;1:853-861). Einthoven, using an improved electrometer and an enhanced correction formula independently of Burch, distinguished five deflections. ${ }^{2}$ He named the deflections $P, Q, R$, $\mathrm{S}$, and $\mathrm{T}$; but why not ABCDE? It is said that Einthoven did not want to compromise the nomenclature of Waller, and thus used later letters of the alphabet. The mathematical convention at that time was to use letters from the second half of the alphabet when introducing a new labeling system. $\mathrm{N}$ had other meanings in mathematics and $\mathrm{O}$ was used for the origin of the Cartesian coordinates. $\mathrm{P}$ was the next letter, and, thereafter, the $Q, R, S$, and $\mathrm{T}$ letters. A few years later in 1903, Einthoven reported the use of the string galvanometer to record

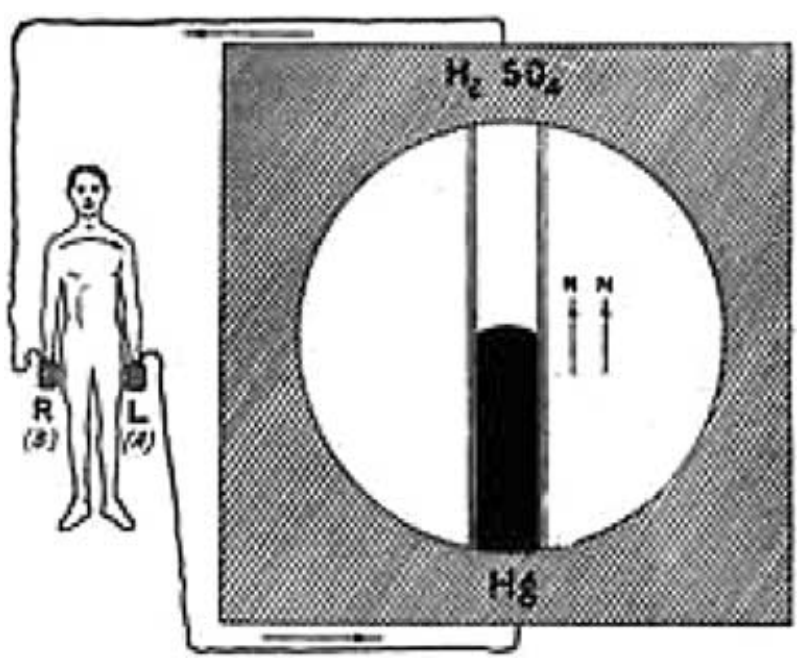

Figure 1. Diagram of Lippmann's capillary electrometer that was first used by Augustus D. Waller to record the electrical activity of the human heart. 
noninvasively the now famous clinical electrocardiogram. ${ }^{3}$

August D. Waller was part of a remarkable family. His father, Augustus V. Waller, was a world-renowned physician who made original contributions about the migration of leukocytes, the vasoconstrictor action of the sympathetic nerves, and death of a nerve when cut distal to the nutrient cell body (Wallernian degeneration). Dr. Waller's daughter, Mary Désirée Waller, was a scientist who made significant contributions in the physics of symmetry and vibrations. Dr. Augustus D. Waller has no living descendents, but the contributions of three generations of this family to medicine, physiology, and physics live on.

\section{REFERENCES}

1. Waller AD. A demonstration on man of electromotive changes accompanying the heart beat. J Physiol 1887;8:229234.

2. Einthoven W. Ueber die Form des menschlichen Electrocardiogrammms. Arch Gesamte Physiol 1895;60:101-123.

3. Einthoven W. Die galvanometrische Registrirung des menschlichen Elektrokardiogramm zugleich eine Beurtheilung der Anwendung des Capillar-Elektrometers in der Physiologie. Pfluger's Arch Gesamte Physiol 1903;99:472-480. 